\title{
Simultaneous Saccharification of Corn Starch in Gluconic Acid Production by Aspergillus niger Immobilized on Nonwoven Fabric in a Pressurized Reactor
}

\author{
Toru Matsui ${ }^{1}$, Katsuya Tooyama ${ }^{2}$ and Seigo Sato ${ }^{2 *}$ \\ ${ }^{1}$ Tropical Biosphere Research Center, Center of Molecular Biosciences, University of the Ryukyus, Japan \\ ${ }^{2}$ Graduate School of Life and Environmental Sciences, University of Tsukuba, Japan
}

\begin{abstract}
Simultaneous saccharification of corn starch and fermentation to gluconic acid (SSF) was examined with Aspergillus niger immobilized on nonwoven fabric under high dissolved oxygen (DO). The starch liquefaction step to maltodextrins by the action of thermostable $\alpha$-amylase was optimized using the dextrose equivalent value as an index. SSF was carried out using liquefied starch with simultaneous addition of commercial amyloglucosidase, and $A$. niger for gluconic acid production at $\mathrm{DO}$ of $150 \mathrm{mg} / \mathrm{l}$ by supplying pressurized oxygen gas. Treatment with $\alpha$-amylase at $86^{\circ} \mathrm{C}$, followed by amyloglucosidase at $30^{\circ} \mathrm{C}$ resulted in nearly $100 \%$ saccharification when using 300 $\mathrm{g} / \mathrm{l}$ corn starch. Under conditions optimized for the saccharification steps, successful repeated batch production of gluconic acid of $272 \mathrm{~g} / \mathrm{l}$ with space-time yield of $6.1 \mathrm{~g} / \mathrm{/} / \mathrm{h}$ was achieved with higher than $90 \%$ production yield from corn starch without significant loss of production activity for $450 \mathrm{~h}$.
\end{abstract}

Keywords: Simultaneous saccharification; Aspergillus niger; Starch; Gluconic acid; Immobilization

\section{Introduction}

Gluconic acid (GA) and its salts are widely used in the food, pharmaceutical and chemical industries, and it has been identified as one of the top 30 building block compounds that can be produced from biomass in future biorefineries [1]. There have been various approaches for GA production by chemical, electrochemical, bioelectrochemical, and photo catalytic approaches [2-4]. Because of some limitations regarding these approaches, microbial processes have been regarded as efficient and dominant techniques for manufacturing GA [5]. To improve its production process, enzymatic biocatalysts in an enzyme bioreactor and microbial production using free-growing or immobilized cells of either Gluconobacter oxydans or Aspergillus niger have been used. Glucose oxidase involved in GA fermentation uses oxygen to convert glucose to GA and, therefore, its overall productivity is strongly dependent on dissolved oxygen (DO) [6]. To increase the oxygen transfer rate in submerged cultures, using oxygen-enriched gas or pressurization of the reactor vessel is an alternative to increasing the stirring speed, air flow rate and so on. Sakurai et al. [7] reported that maximum productivity was obtained at DO up to $150 \mathrm{mg} / \mathrm{l}$, which could be attained only with pressurized oxygen gas supplementation. Immobilization of whole cells or glucose oxidase enzyme by various techniques has also been reported to be a useful approach for the production of GA. Nonwoven fabric has been used as a support for immobilizing proteins [8] or whole cells [9] since it is porous, has a large surface area, and can be easily processed. In addition, it is feasible to use cheap raw materials such as cellulose, molasses, starch and whey for the fermentation, and simultaneous saccharification of such materials for the fermentation (SSF) has been used in an efficient process with ethanol [10,11], lactic acid $[12,13]$, etc. Since SSF for GA production from starch is considered to be comprised of starch solubilization by heating, followed by the liquefaction/saccharification of starch and GA production, thermostable or thermophilic amylase aided liquefaction might be useful to avoid the gelatinization of the solubilized starch.

In this study, production of GA from starch in a oxygen pressurized reactor was optimized for efficient repeated production with Aspergillus niger immobilized on nonwoven fabric with the use of thermostable amylase from Bacillus sp. for liquefaction of starch.

\section{Materials and Methods}

\section{Chemicals}

Amyloglucosidase (AMG) from Rhizopus sp. (11,600 units/gprotein), and $\alpha$-amylase (AAM) from Bacillus subtilis (20,000 units/ g-protein) were purchased from Sigma-Aldrich Inc. (St Louis, MO), and Wako Pure Chemical Industries Ltd., Osaka, Japan), respectively. Nonwoven fabric, made of a rayon and polyacrylonitrile mixture (RA), was prepared and kindly supplied by Japan Vilene Co. Ltd. (Tokyo, Japan). All other materials were of the highest purity commercially available and were used without further purification.

\section{Microorganism and media}

Aspergillus niger JCM5549 (formerly IAM2094) was used throughout this study. Medium compositions used for stock culture (namely medium A), sporulation (medium B), and mycelial growth (medium $\mathrm{C}$ ) are shown in Table 1.

Sequential hydrolysis of cornstarch by $a$-amylase and amyloglucosidase: Enzymes concentrations used for sequential hydrolysis of corn starch were optimized by analyzing in terms of the dextrose equivalent (DE) for the liquefaction step using a-amylase, and glucose produced in the saccharification step using amyloglucosidase. DE value was calculated by the following equation [14]:

*Corresponding author: Seigo Sato, Graduate School of Life and Environmental Sciences, University of Tsukuba, Japan, Tel: +81-298-53-4608; Fax: +81-298-534605; E-mail: sato.seigo.ge@u.tsukuba.ac.jp

Received October 10, 2013; Accepted October 23, 2013; Published October 28 2013

Citation: Matsui T, Tooyama K, Sato S (2013) Simultaneous Saccharification of Corn Starch in Gluconic Acid Production by Aspergillus niger Immobilized on Nonwoven Fabric in a Pressurized Reactor. J Microb Biochem Technol 5: 088-091. doi:10.4172/1948-5948.1000106

Copyright: $\odot 2013$ Matsui T, et al. This is an open-access article distributed under the terms of the Creative Commons Attribution License, which permits unrestricted use, distribution, and reproduction in any medium, provided the original author and source are credited 
Citation: Matsui T, Tooyama K, Sato S (2013) Simultaneous Saccharification of Corn Starch in Gluconic Acid Production by Aspergillus niger Immobilized on Nonwoven Fabric in a Pressurized Reactor. J Microb Biochem Technol 5: 088-091. doi:10.4172/1948-5948.1000106

\begin{tabular}{|c|c|c|c|}
\hline & A & B & C \\
\hline Glucose & $30 \mathrm{~g}$ & $20 \mathrm{~g}$ & $30 \mathrm{~g}$ \\
\hline Yeast Extract & $\mathrm{n} / \mathrm{a}^{*}$ & $\mathrm{n} / \mathrm{a}$ & $9 \mathrm{~g}$ \\
\hline Malt Extract & $1 \mathrm{~g}$ & $4.5 \mathrm{~g}$ & $9 \mathrm{~g}$ \\
\hline Peptone & $0.25 \mathrm{~g}$ & $0.2 \mathrm{~g}$ & $15 \mathrm{~g}$ \\
\hline $\mathrm{MgSO}_{4} \cdot 7 \mathrm{H}_{2} \mathrm{O}$ & $0.1 \mathrm{~g}$ & $0.12 \mathrm{~g}$ & $\mathrm{n} / \mathrm{a}$ \\
\hline $\mathrm{KH}_{2} \mathrm{PO}_{4}$ & $0.12 \mathrm{~g}$ & $0.15 \mathrm{~g}$ & $\mathrm{n} / \mathrm{a}$ \\
\hline$\left(\mathrm{NH}_{4}\right)_{2} \mathrm{HPO}_{4}$ & $\mathrm{n} / \mathrm{a}$ & $0.5 \mathrm{~g}$ & $\mathrm{n} / \mathrm{a}$ \\
\hline $\mathrm{NH}_{4} \mathrm{NO}_{3}$ & $0.23 \mathrm{~g}$ & $\mathrm{n} / \mathrm{a}$ & $\mathrm{n} / \mathrm{a}$ \\
\hline $\mathrm{CaCO}_{3}$ & $4 \mathrm{~g}$ & $\mathrm{n} / \mathrm{a}$ & $\mathrm{n} / \mathrm{a}$ \\
\hline $\mathrm{Agar}$ & $20 \mathrm{~g}$ & $8 \mathrm{~g}$ & \\
\hline Distilled Water & $1 \mathrm{~L}$ & $1 \mathrm{~L}$ & $1 \mathrm{~L}$ \\
\hline $\mathrm{pH}$ & 6.0 & 6.0 & 6.0 \\
\hline
\end{tabular}

*n/a - not applicable

Table 1: Medium Composition used in this study.

$\mathrm{DE}=$ reducing sugar content/total solids content $\times 100$

Starch liquefaction was carried out by adding various concentrations of AAM to a solution composed of $300 \mathrm{~g}$ corn starch, $0.15 \mathrm{~g}$ $\mathrm{MgSO}_{4} \cdot 7 \mathrm{H}_{2} \mathrm{O}, 0.2 \mathrm{~g} \mathrm{KH}_{2} \mathrm{PO}_{4}, 0.4 \mathrm{~g} \mathrm{Na}_{2} \mathrm{HPO}_{4}$, and $0.5 \mathrm{~g} \mathrm{CaCl}_{2} \cdot 2 \mathrm{H}_{2} \mathrm{O}$ in $1,000 \mathrm{ml}$ deionized water, $\mathrm{pH} 6.0$, at $86^{\circ} \mathrm{C}$, with a magnetic stirrer. The saccharification test using AMG was carried out at $30^{\circ} \mathrm{C}$ using the liquefied solution prepared as described above.

SSF of corn starch in GA production: GA production from liquefied starch with immobilized $A$. niger was performed in a pressureproof column reactor as described previously [7]. Mycelia immobilized on $9.5 \mathrm{~cm} \times 8 \mathrm{~cm}$ and $18.5 \mathrm{~cm} \times 9.5 \mathrm{~cm}$ nonwoven fabric wound onto stainless steel cylindrical wire, prepared as described above, placed in the column reactor with $600 \mathrm{ml}$ liquefied starch solution prepared as described above, was incubated at $30^{\circ} \mathrm{C}$, under pressurization at $7 \mathrm{MPa}$ and supplied with sterile oxygen gas through sintered glass filters. DO in the reactor was monitored using a DO probe (galvanic oxygen electrode Type DY-1; B. E. Marubishi Co. Ltd., Tokyo, Japan) to maintain $\mathrm{DO}$ at $150 \mathrm{mg} / \mathrm{l}$.

Analysis: Glucose, oligosaccharide, and gluconic acid were analyzed using HPLC (L-6000; Hitachi, Ltd., Japan). For glucose and oligosaccharide analysis, a refractive index (RI) detector (Shodex RI SE-51; Showa Denko Co. Ltd., Tokyo, Japan) with a column packed with Aminex HPX-42C (Bio-Rad Laboratories Inc., Richmond, $\mathrm{CA})$ was employed with deionized water as an eluent. For gluconic acid analysis, a UV detector (210 nm) with a column MCI GEL 08S (Mitsubishi Chemical Co., Tokyo, Japan) was employed with a mobile phosphate phase. The dry weight of immobilized cells was determined by subtraction of the average predetermined dry weight of nonwoven fabrics from the weight of nonwoven fabrics plus mycelium after drying at $80^{\circ} \mathrm{C}$ to a constant weight. Reducing sugar was determined by a modified Somogyi method [15]. The mutarotase-GOD method was also used for monitoring glucose in the pressurized bioreactor using the Glucose-C-test (Wako Pure Chemical Industries Ltd.) according to the manufacturer's instructions.

\section{Results and Discussion}

\section{Optimization of starch saccharification with a-amylase and} amyloglucosidase

Enzymatic hydrolysis of starch to glucose involves the liquefaction of gelatinized starch with acid or thermostable $a$-amylase followed by saccharification to glucose by amyloglucosidase [16]. For the liquefaction step using AAM, the effect of AAM concentration on the DE value was examined as shown in Figure 1. With an AAM concentration higher than $0.01 \%$, DE rapidly increased within $30 \mathrm{~min}$ to a nearly saturated level of 20 , although $0.003 \%$ AAM reached less than $1 \mathrm{DE}$ after $50 \mathrm{~min}$. With $0.005 \%$ AAM, $10 \mathrm{DE}$ could be obtained after $30 \mathrm{~min}$. Gupta et al. [17] optimized the natural starch hydrolysis conditions with a liquefaction step to obtain 10 DE using AAM, followed by a saccharification step to DE 96 using AMG. In our case, $0.005 \%$ AAM treated for 30 min was concluded to be optimal for the liquefaction step.

Saccharification of liquefied corn starch with AMG was examined as shown in Figure 2. With AMG $>0.4 \%,>100 \mathrm{~g} / \mathrm{l}$ glucose was obtained



(B)

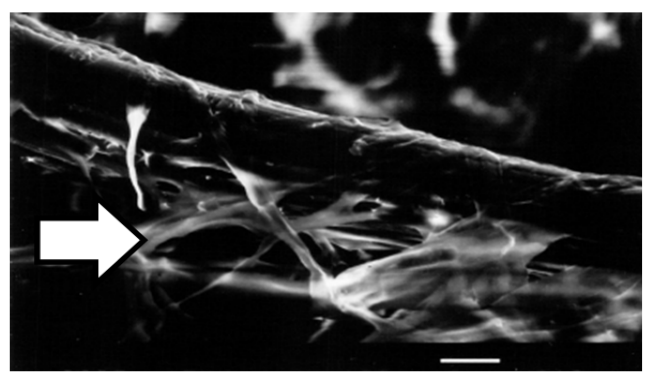

$10 \mu \mathrm{m}$

Figure 1: Effect of $\alpha$-amylase (AAM) concentration on dextrose equivalent (DE) of corn starch. $\Delta: 0.003 \%, \bullet: 0.005 \%, \square: 0.01 \%, \circ: 0.02 \%$

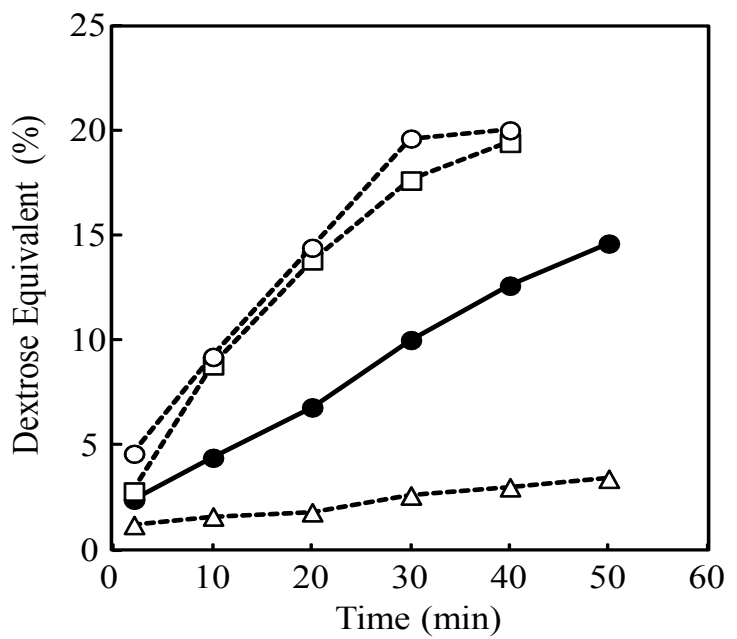

Figure 2: Effect of amyloglucosidase (AMG) concentration on saccharification of corn starch. $\Delta: 0.2 \%, \circ: 0.3 \%, \bullet: 0.4 \%, \square: 0.5 \%$ 
Citation: Matsui T, Tooyama K, Sato S (2013) Simultaneous Saccharification of Corn Starch in Gluconic Acid Production by Aspergillus niger Immobilized on Nonwoven Fabric in a Pressurized Reactor. J Microb Biochem Technol 5: 088-091. doi:10.4172/1948-5948.1000106

in $1 \mathrm{~h}$ reaching nearly $300 \mathrm{~g} / \mathrm{l}$ in $6 \mathrm{~h}$, although the saccharification rate slightly decreased with $0.3 \%$ AMG. HPLC analysis of the byproducts formed after the reaction showed maltose $(4.36 \mathrm{~g} / \mathrm{l})$ and maltotriose $(1.05 \mathrm{~g} / \mathrm{l})$, suggesting that higher than $98 \%$ of the liquefied corn starch was saccharified under this condition. Therefore, $0.4 \%$ AMG was concluded to be suitable for saccharification in GA production to avoid the limitation of glucose feeding. Table 2 shows the results obtained with various starches under the conditions determined as above. All the starches tested except for soluble starch generated nearly $100 \%$ glucose.

\section{Repeated batch production of gluconic acid from starch}

GA production was further examined using the liquefied solution of starch with immobilized A. niger. Immobilization of mycelia was carried out as described previously [7]. Briefly, nonwoven fabric wound around stainless steel cylindrical wire was soaked in medium $\mathrm{C}$ containing $4 \times 106$ to $8 \times 106$ spores per $\mathrm{ml}$ for a few minutes, followed by aseptic incubation in oxygen gas at $30^{\circ} \mathrm{C}$ for $45 \mathrm{~h}$. As shown in Figure 3 , the mycelia grew well not only on the surface but also penetrated the nonwoven fabric and interwined with the fiber. Dense growing of the mycelia mainly near the surface of the fabric could be due that the strain was aerobic growing fungus. For efficient production of gluconic acid, the bioreactor was used at DO of 150-200 $\mathrm{mg} / \mathrm{l}$ by supplying oxygen gas at a pressure of ca $7 \mathrm{MPa}$. As shown in Figure 4, successful production of GA for at least 10 repetitions was achieved without a significant loss of production activity. Ten repeated batch productions resulted in an average of $272.2 \pm 14.7 \mathrm{~g} / \mathrm{l}(1.39 \pm 0.075 \mathrm{M}) \mathrm{GA}$ production, and space-time yield of $6.1 \pm 1.06 \mathrm{~g} / \mathrm{l} / \mathrm{h}(31.1 \pm 5.41 \mathrm{mM} / \mathrm{h})$. In all the batches, oxalate, a possible byproduct formed in GA fermentation,

\begin{tabular}{|c|c|c|}
\hline Starch & D.E. (-)* & Glucose (g/l) \\
\hline Corn starch & 10 & 294.3 \\
\hline Potato starch & 12 & 298.8 \\
\hline Sweet potato starch & 9.6 & 298.8 \\
\hline Soluble starch & 11.6 & 228.2 \\
\hline
\end{tabular}

All reactions were carried out with $300 \mathrm{~g} / \mathrm{l}$ starch under conditions as optimized for corn starch

*Dextrose equivalent value after liquefaction with AAM

Table 2: Sequential saccharification of various starches with AAM and AMG.

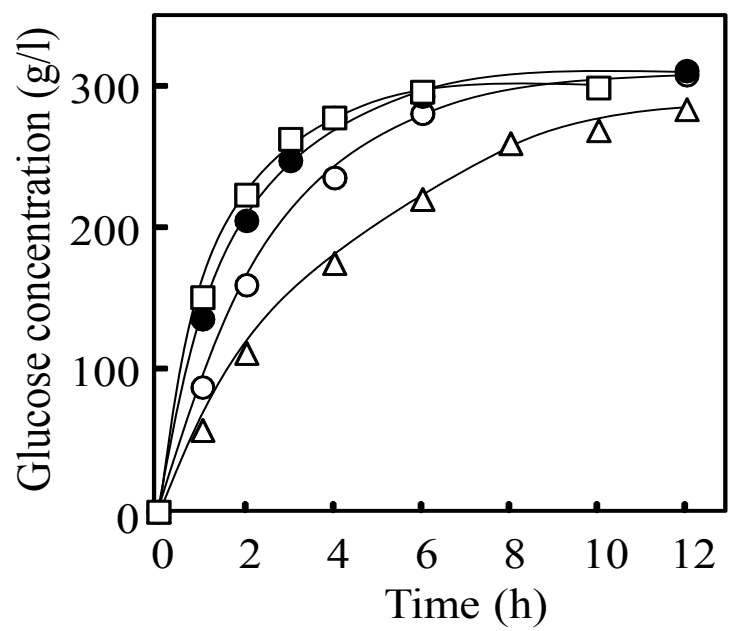

Figure 3: Photographs of mycelial cells immobilized on nonwoven fabric RA using (A) microscope (x50) and (B) SEM (x1100). Arrows indicate mycelia.

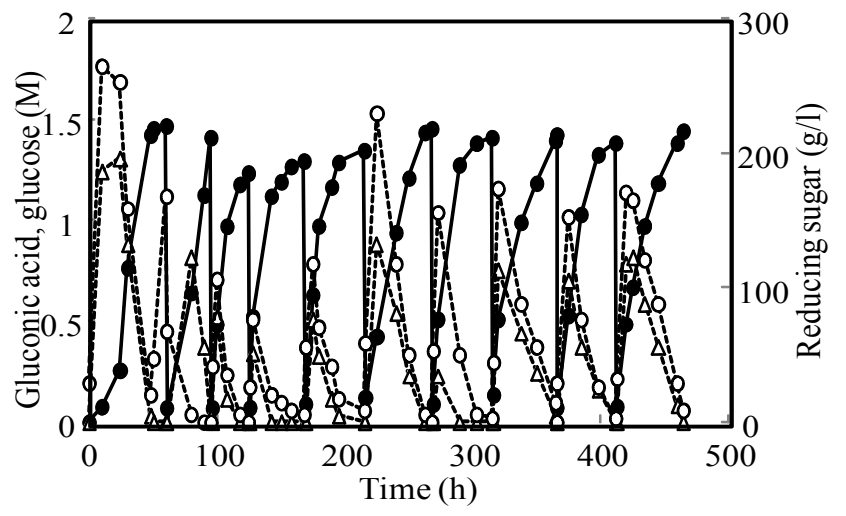

-: GA (g/l), ०: Reducing sugar (g/l), $\Delta$ : glucose $(\mathrm{g} / \mathrm{l})$

Figure 4: Repeated batch production of GA from liquefied corn starch using $A$. niger immobilized on nonwoven fabric.

\begin{tabular}{|l|l|l|l|l|}
\hline GA (g/l) & $\begin{array}{l}\text { Yields } \mathbf{( \% g - G A / g -} \\
\text { substrate) } \mathbf{( g / l / h )}\end{array}$ & $\mathbf{S T Y}^{*} \mathbf{( g / l / h )}$ & Substrate & References \\
\hline 272.1 & 90.7 & 6.1 & Corn starch & This study** \\
\hline 85.2 & 86.97 & 1.94 & Golden syrup & {$[5]$} \\
\hline 143 & 95 & 2.4 & Hydrol & {$[18]$} \\
\hline $80-100$ & $60-67$ & 0.047 & Waste paper & {$[20]$} \\
\hline $80-85$ & 80.4 & $0.67-0.71$ & Grape must & {$[21]$} \\
\hline
\end{tabular}

*Space time yield

** Mean values calculated from 10 repeated batch productions

Table 3: Studies in gluconic acid (GA) production with fungus.

was a mean value of $0.33 \mathrm{~g} / \mathrm{l}$. Recent reports of GA production from unconventional carbohydrate sources are summarized in Table 3. Addition to the high production yield by the substrate and successful accumulation of GA at significantly higher concentration than in other studies suggest that our SSF system could be feasible for industrial applications. The space-time yield in this study corresponds to nearly three-fold that in a previous report [18], which could be due to the reaction being performed at high $\mathrm{DO}$, which could be achieved only by using an oxygen gas-supplied pressurized reactor. The specific GA production rate in this study was $6.91 \mathrm{~g}-\mathrm{GA} / \mathrm{g}$-mycelia/h. A previous study of the same strain of free cells, using glucose as the substrate was reported to be 19.6 g-gluconate/g-mycelia/h [19], approximately 3 -fold that of this study; however, our system seems to have more feasible operability for continuous or repeated-batch production.

\section{Conclusions}

This paper shows that the microbial GA production from corn starch using Aspergillus niger. Optimization of the liquefaction of the starch by thermostable AAM, followed by the saccharification by AMG generated glucose with nearly $100 \%$ yield in $6 \mathrm{~h}$, which could supply enough amount of glucose for GA production. Present data suggest that the direct using of the liquefied solution for GA production containing AMG was successful in case of our system. Combination of the saccharification and GA production under high DO using $A$. niger immobilized on nonwoven fabrics resulted in the efficient GA production (6.1 g-GA/l/h). In addition, our immobilizing system resulted in the stable repeated batch production at such level. Our system might also have an advantage in the operation of the bioreactor preventing contamination because of the high DO [22]. 
Citation: Matsui T, Tooyama K, Sato S (2013) Simultaneous Saccharification of Corn Starch in Gluconic Acid Production by Aspergillus niger Immobilized on Nonwoven Fabric in a Pressurized Reactor. J Microb Biochem Technol 5: 088-091. doi:10.4172/1948-5948.1000106

\section{References}

1. Werpy $T$, Peterson $G$ (2004) Top value added chemicals from biomass. Volume I-results of screening for potential candidates from sugars and synthesis gas. U.S. Department of Energy.

2. Isbell HS, Frush HL, Bates FJ (1932) Manufacture of Calcium Gluconate by electrolytic oxidation of glucose. Ind Eng Chem Res 24: 375-378.

3. De Wilt HGJ (1972) Oxidation of glucose to gluconic acid. Ind Eng Prod Res Develop 11: 370-378.

4. Colmenares JC, Magdziarz A, Bielejewska A (2011) High-value chemicals obtained from selective photo-oxidation of glucose in the presence of nanostructured titanium photocatalysts. Biores Technol 102: 11254-11257.

5. Purane NK, Sharma SK, Salunkhe PD, Labade DS, Tondikar MM (2012) Gluconic acid production from golden syrup by Aspergillus niger strain using semiautomatic stirred-tank fermenter. J Microb Biochem Technol 4: 92-95.

6. Moresi M, Parente E, Mazzatura A (1991) Effect of dissolved oxygen concentration on repeated production of gluconic acid by immobilised mycelia of Aspergillus niger. Appl Microbiol Biotechnol 36: 320-323.

7. Sakurai H, Lee HW, Sato S, Mukataka S, Takahashi J (1989) Gluconic acid production at high concentrations by Aspergillus niger immobilized on a nonwoven fabric. J Ferment Bioeng 67: 404-408

8. Yang WJ, Yang CS, Huang CJ, Chen KS, Lin SF (2012) Bostrycin, a novel coupling agent for protein immobilization and prevention of biomaterialcentered infection produced by Nigrospora sp. No. 407. Enzyme Microb Technol 50: 287-92.

9. Chen JP, Lin GH (2010) Optimization of biodiesel production catalyzed by fungus cells immobilized in fibrous supports. Appl Biochem Biotechnol 161 : 181-194.

10. Bandaru VV, Bandaru SR, Somalanka SR, Mendu DR, Imandi SB, et al. (2007) Optimization of fermentation parameters to enhance the production of ethanol from palmyra jaggery using Saccharomyces cerevisiae in a batch fermentor Appl Biochem Biotechnol 143: 224-235.

11. Srichuwong S, Fujiwara M, Wang X, Seyama T, Shiroma R, et al. (2009)
Simultaneous saccharification and fermentation (SSF) of very high gravity (VHG) potate mash for the production of ethanol. Biomass Bioenergy 33: 890898.

12. Hofvendahl K, Hahn-Hagerdal B (2000) Factors affecting the fermentative lactic acid production from renewable resources (1). Enzyme Microb Technol 26: 87-107.

13. Huang LP, Jin B, Lant $P$ (2005) Direct fermentation of potato starch wastewater to lactic acid by Rhizopus oryzae and Rhizopus arrhizus. Bioprocess Biosystems Eng 27: 229-238.

14. Sun J, Zhao R, Zeng J, Li G, Li X (2010) Characterization of dextrins with different Dextrose Equivalents. Molecules 15: 5162-73.

15. Kobayashi T, Tabuchi T (1954) A method employing a tribasic sodium phosphate buffered reagent for estimating semimicro quantities of reducing sugars. J Agric Chem Soc Japan 28: 171-174.

16. Shankar V, Nehete PN, Kothari RM (1993) Immobilization of amyloglucosidase. Ind J Biochem Biophys, 30: 62-70.

17. Gupta K, Jana AK, Kumar S, Maiti M (2013) Immobilization of alpha-amylase and amyloglucosidase onto ion-exchange resin beads and hydrolysis of natural starch at high concentration. Bioprocess Biosystems Eng 36: 1715-24

18. Vassilev NB, Vassileva MC, Spassova DI (1993) Production of gluconic acid by Aspergillus niger immobilized on polyurethane foam. Appl Microbiol Biotechnol 39: $285-288$.

19. Lee HW, Sato S, Mukataka S Takahashi J (1987) Studies on the production of gluconic acid by Aspergillus niger under high dissolved oxygen concentration. Hakkokogaku 65: 501-506.

20. Ikeda Y, Park EY, Okuda N (2006) Bioconversion of waste office paper to gluconic acid in a turbine blade reactor by the filamentous fungus Aspergillus niger. Biores Technol 97: 1030-1035.

21. Singh OV, Singh RP (2006) Bioconversion of grape must into modulated gluconic acid production by Aspergillus niger ORS-4.410. J Appl Microbiol, 100: 1114-1122.

22. Sato S, Yajima T, Mukataka S, Takahashi J (1995) Protection of bioreactor from microbial contamination by high dissolved oxygen tension. Biotechno Technique 9: 383-389. 